\title{
FACTORS AFFECTING ANEMIA IN PREGNANT WOMEN WITH SECOND AND THIRD TRIMESTER OF PREGNANCY AT TIRON COMMUNITY HEALTH CENTER, KEDIRI DISTRICT, EAST JAVA
}

\author{
Dewi Kartika Sari, Putri Wahyu Wigati
}

\author{
Universitas Kadiri
}

\begin{abstract}
Background: Anemia is a pathologic condition produced by a decrease in red blood cell mass or a decrease in the amount of hemoglobin. The initial survey carried out in the Tiron Puskesmas work area in the June-July 2019 period was still a high incidence of anemia in the Tiron Puskesmas Kediri Regency work area (60\%). This study aimed to analyze factors affecting anemia in pregnant women with second and third trimester of pregnancy at tiron community health center, Kediri district, East Java.

Subjects and Method: A cross sectional study was carried out at Tiron community health center, Kediri, East java, from June to July 2020. A sample of 49 2nd and 3rd trimesters of pregnant women was selected by purposive sampling. The dependent variable was anemia. The independent variables were age, iron tablet intake, ANC visit. The data were collected by questionnaire and analyzed by a multiple logistic regression.

Results: Anemia in pregnant women decreased with older age $(\mathrm{OR}=0.08 ; 95 \% \mathrm{CI}=0.01$ to 1.20; $\mathrm{p}=0.068)$. Anemia in pregnant women increased with irregular iron tablet intake $(\mathrm{OR}=$ $18.45 ; 95 \% \mathrm{CI}=2.77$ to $123.10 ; \mathrm{p}=0.003)$ and irregular $\mathrm{ANC}$ visit $(\mathrm{OR}=1.85 ; 95 \% \mathrm{CI}=1.05$ to $38.18 ; \mathrm{p}=1.87$ ).

Conclusion: Anemia in pregnant women decreases with older age. Anemia in pregnant women increases with irregular iron tablet intake and irregular ANC visit.
\end{abstract}

Keywords: anemia, hemoglobin levels, pregnant women

Correspondence:

Dewi Kartika Sari. Faculty of Health Sciences Universitas Kadiri. Jl. Selomangleng No 1, Kediri. Email: dewikartika@unik-kediri.ac.id 